
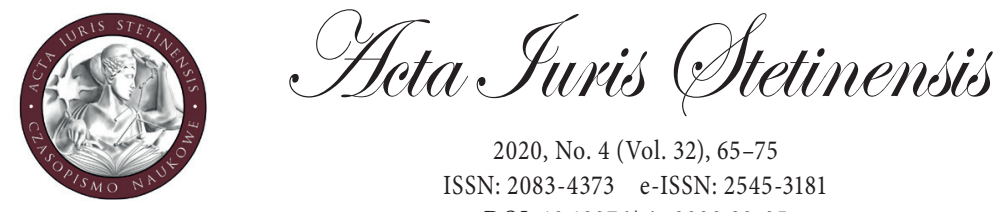

2020, No. 4 (Vol. 32), 65-75

ISSN: 2083-4373 e-ISSN: 2545-3181

DOI: $10.18276 /$ ais.2020.32-05

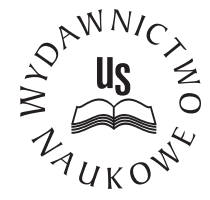

Justyna Pierewoj

Ph.D. student

OPEN ACCESS

University of Bialystok, Poland

Faculty of Law

e-mail: j.pierewoj@uwb.edu.pl



ORCID ID: 0000-0002-8580-7238

\title{
Misleading advertising practices for medicinal products and dietary supplements - selected legal and practical aspects
}

\begin{abstract}
The paper constitutes an attempt at analysing the issue of misleading advertising practices for medicinal products and dietary supplements. Furthermore, the aim of the paper is to provide an answer to the question whether the binding legal regulations concerning advertisement of medicinal products and dietary supplements sufficiently protect consumers against being misled. While studying the topic in question, the research method of examining applicable laws was used, through the agency of the analysis of legal provisions referring to the indicated issue and confrontation thereof with the practice applied in advertising medicinal products and dietary supplements. As a result of the conducted analysis of the indicated issue a conclusion has been drawn that the use of certain advertising practices on the pharmaceutical market may mislead consumers, which has a negative impact on public health. Having in mind the need for strengthening the consumers' protection against the unfair advertisements of medicinal products and dietary supplements, the problems have been identified and the article proposes introduction of legal regulations aimed at improving the consumers' protection against practices that may be misleading.
\end{abstract}

Keywords: misleading advertising practices, advertisement of medicinal products and dietary supplements, umbrella branding, pharmaceutical and nutritional safety, the right to a safe pharmaceutical market 


\section{Introduction}

The intensive development of the pharmaceutical industry can be observed through the agency of the omnipresent advertising. In compliance with the second recital of the preamble of Directive 2001/83/EC the essential aim of any rules governing the production, distribution and use of medicinal products must be to safeguard public health. ${ }^{1}$ Despite not specifying therein separately the advertisement of medicines, the indicated rules fully apply thereto. ${ }^{2}$

Various marketing efforts significantly influence decisions taken by consumers with regard to purchasing OTC (over the counter) medicines and dietary supplements. ${ }^{3}$ An average patient does not notice any difference between them and it should be underlined that from the legal point of view dietary supplements are a specific category of foodstuffs aimed at supplementing a normal diet. ${ }^{4}$ Television, radio and press messages are full of assurances of the multitude of usages of advertised products. The omnipresent advertising of OTC medicines and dietary supplements results in those products becoming common and intensifies the frequency of use thereof by consumers. ${ }^{5}$ The vast majority of those advertisements create in the consumer the need for purchasing them and the messages included therein are often far from reliability both in terms of form and content thereof. ${ }^{6}$

\section{Legal status of a medicinal product and a dietary supplement}

Products available for purchase in a pharmacy or pharmacy outlets are mainly associated with medicines and are colloquially called such. In reality, the situation is much more complex, since a pharmacy offers medicinal products available on

1 Directive 2001/83/EC of the European Parliament and of the Council of 6 November 2001 on the Community code relating to medicinal products for human use, OJ L 311, 28.11.2001, pp. 67-128, p. 67.

2 Ignatowicz, Z., Reklama produktów leczniczych, in: Olszewski, W.L. (ed.) Prawo farmaceutyczne. Komentarz, Warszawa 2016, p. 604.

3 Supreme Audit Office, Dopuszczenie do obrotu suplementów diety, 2017, https://www.nik.gov.pl/ (accessed 01.02.2020).

4 Act of 25 August 2006 on food and nutrition safety, Dz.U. (Journal of Laws) of 2006, No. 171, item 1225 , as amended, hereinafter also FNSA.

5 Mokrysz-Olszyńska, A., Reklama suplementów diety jako wyzwanie dla ustawodawcy i regulatora, "Roczniki Administracji i Prawa" 2016, Vol. 16(2), pp. 234.

6 Ministry of Health, Polityka Lekowa Państwa 2018-2022, 2018, https://www.gov.pl/web/zdrowie (accessed 01.02.2020). 
prescription (Rx or Rp), without prescription (OTC), medical devices, dietary supplements and cosmetics. ${ }^{7}$

In compliance with Article 2 par. 32 of the Act - the Pharmaceutical Law (hereinafter $\mathrm{PhL}$ ): 'a medicinal product shall mean any substance or combination of substances presented as able to prevent or treat diseases, or administered with a view to making a medical diagnosis or to restoring, correcting, or modifying physiological functions of an organism through pharmacological, immunological or metabolic action. ${ }^{3}$ Among many tasks of the Chief Pharmaceutical Inspectorate stipulated in the aforementioned Act, the most important for the protection of human health and life is the supervision over the quality of medicinal products. The tasks of the Main Pharmaceutical Inspector are specified in details in Article $115 \mathrm{PhL}$, including, among others, issuing decisions in the scope of giving consent (refusing to give, amending, withdrawing) to manufacturing medicinal products, issuing decisions ordering cessation of broadcasting or carrying out the advertising of medicinal products non-compliant with binding provisions.

Whereas, in compliance with Article 3 par. 3 point 39 of the Act of 25 August 2006 on food and nutrition safety (hereinafter also FNSA), a dietary supplement is foodstuff aimed at supplementing a normal diet. According to some researchers it would be more accurate to use the phrase 'food supplements'. This phrase was used by the European legislator in Directive 2002/46/EC of the European Parliament and of the Council of 10 June 2002 on the approximation of the laws of the Member States relating to food supplements. ${ }^{10}$ In Poland, the Chief Sanitary Inspectorate is responsible for the trade in this group of products. The procedure consists in submitting by the entrepreneur an application including the name of the product which is verified under an investigation procedure regarding detection of any legal non-compliances and confirmation that the given dietary supplement does not have features of a medicinal product (Article 8 FNSA). In contrast to medicinal products, in the case of dietary supplements, it is not required to conduct clinical research and registration procedure. It has a significant impact on the possibility

7 Regulation of the Minister of Health of 14 November 2008 on the criteria for passing medicinal products to individual availability categories, Dz.U. (Journal of Laws) of 2008, No. 206, item 1292, as amended.

8 Act of 6 September 2001 - Pharmaceutical Law, Dz.U. (Journal of Laws) of 2001, No. 126, item 1381, as amended, hereinafter also PhL.

9 Directive 2002/46/EC of the European Parliament and of the Council of 10 June 2002 on the approximation of the laws of the Member States relating to food supplements, OJ L 183, 12.7.2002, pp. 51-57, p. 51.

Szczęsny, R., Reklama farmaceutyczna i pokrewna, Warszawa 2010, p. 526. 
of confirming safety of a given product, as well as benefits from using it. ${ }^{11}$ Furthermore, manufacturers of dietary supplements are not obliged to post on the packaging any information regarding interactions of the supplement with alcohol and other substances or medicines. In compliance with Article 104 par. 1 FNSA, due to the non-adherence to the requirements in the scope of marking, including presentation and advertising of dietary supplements, a financial penalty, imposed by the state voivodeship sanitary inspector in a form of a decision, has been provided for.

\section{Advertising of medicinal products and dietary supplements - selected legal aspects}

In compliance with Article 52 par. $1 \mathrm{PhL}$, advertising a medicinal product means an activity consisting in informing about or encouraging to use medicinal products aimed at increasing the number of issued prescriptions, delivery, sales or consumption of medicinal products. The quoted wording of the Article indicates that the aim of the message is underlined instead of the contents thereof. An advertisement for a medicinal product must not be misleading, it should present the medicinal product objectively and inform about its rational use (Article 53 par. 1).

The Act on food and nutrition safety does not include a definition of an advertisement despite using this concept many times. In compliance with Article 27 par. 5, an advertisement for dietary supplements cannot include information stating or suggesting that a balanced and diverse diet cannot deliver the quantity of nutrients sufficient for the body. Whereas, Article 7 of Regulation No. 1169/2011 of the European Parliament and of the Council of 25 October 2011 states that misleading advertising is forbidden, which can happen, among others, by attributing to the food effects or properties which it does not possess. ${ }^{12}$ Moreover, regulations referring to the so-called nutrition and health claims, included in Regulation No. 1924/2006 of the European Parliament and of the Council of 20 December 2006 (Article 12) forbid the use of claims which make reference to recommendations of individual doctors or health professionals in the scope of health. ${ }^{13}$

11 Pierewoj, J., Suplement diety a bezpieczeństwo konsumentów - wybrane aspekty prawa polskiego oraz prawa Unii Europejskiej, in: Porzeżyński, M. and Borcuch A. (eds.), Bezpieczeństwo w erze społeczeństwa informacyjnego. Wyzwania w sferach kultury, marketingu i gospodarki, Kielce 2019, pp. 110-112.

12 Regulation (EU) No. 1169/2011 of the European Parliament and of the Council of 25 October 2011 on the provision of food information to consumers, OJ L 304, 22.11.2011, pp. 18-63.

13 Regulation (EC) No. 1924/2006 of the European Parliament and of the Council of 20 December 2006 on nutrition and health claims made on foods, OJ L 404, 30.12.2006, pp. 9-25. 
The joint principle concerning both medicinal products and dietary supplements consists in the ban on misleading advertisements. In both the national and European Union judicial decisions the premise of misleading the consumer should be considered with the use of 'the average consumer model. ${ }^{14}$ In compliance with the judicial decisions of the Court of Justice, it is a consumer who is sufficiently informed and sufficiently careful and attentive with the consideration of social, cultural and linguistic factors, however, with the simultaneous consideration of preventing abusing customers, features of whom make them especially vulnerable to unfair commercial practices. ${ }^{15}$ Therefore, it should be underlined that recipients of advertisements for medicine are a special group of consumers, often with lowered ability to perceive and conduct a reasonable and critical assessment of messages targeted at them. Furthermore, a large group of consumers of medicinal products are also seniors.

\section{The umbrella branding and advertisement of medicinal products and dietary supplements}

The only similarity between medicines and dietary supplements consists in their form and shape, since in both cases those are tablets, capsules, sachets. A consumer or a patient can mistake a dietary supplement for a medicine; it is possible in three variants:

1) the consumer purchasing a dietary supplement while believing that they are buying a medicine they intended to purchase (e.g. due to the identical trademark);

2) purchasing a dietary supplement while believing that, if its trademark is very similar to the medicine, it has identical therapeutic use as the medicine;

3) purchasing a medicine while believing that they are buying a dietary supplement. ${ }^{16}$

The Report of the Supreme Audit Office indicates a number of irregularities concerning dietary supplement advertisements ${ }^{17}$ one of them being the abuse of the umbrella branding in the pharmaceutical sector. It consists in the introduction

14 Case C-210/96 - Gut Springenheide GmbH and Rudolf Tusky v Oberkreisdirektor des Kreises Steinfurt, ECLI:EU:C:1998:369.

15 Kondrat, M. et al., Prawo suplementów diety, Warszawa 2012, p. 60.

16 Roszak, M., Granice stosowania praktyki umbrella brandingu (znaków parasolowych) na rynku farmaceutycznym, in: Kępiński, M. (ed.), Rynek farmaceutyczny, a prawo własności intelektualnej, Warszawa 2013, p. 139.

17 Supreme Audit Office, op. cit. 
of a new product within an already existing umbrella brand. ${ }^{18}$ The sales strategy of whole lines of products under the same trademark is aimed at generating profit by increasing the probability of product purchases of the same brand by consumers. ${ }^{19}$ The new product usually is not much different in terms of the name, yet at the same time it includes other active substances, and thus has a different effect on the human body.

Introduction of new products within the umbrella branding helps decrease the costs of advertising and marketing, while at the same time promotes a larger number of products with one advertising campaign. Furthermore, it is favourable in dynamic markets with short life-cycle products, since it is easier to convince and gain the trust of customers who know the given umbrella brand. Increasing interactions between the brand and the customer may lead to the increase in the given brand's value and transfer the increase in value to other products and categories. ${ }^{20}$

It should be underlined that, in principle, umbrella branding is not covered by the object of legal regulations. Whereas application of a uniform umbrella brand for marking a medicinal product and a dietary supplement may constitute an act of unfair competition pursuant to the Act of 16 April 1993 on combating unfair competition, hereinafter also UCA (Article 10 and 3 par. 2) ${ }^{21}$ Furthermore, in some cases, provisions of the Act of 23 August 2007 on the prevention of unfair market practices (hereinafter PUMPA) may apply, since unfair market practice refers in particular to, misleading market practice (Article 4 par. 2 and Article 5 par. 1 PUMPA). ${ }^{22}$

As a result of the insufficient legal regulations regarding advertising medicines and dietary supplements, the Minister of Health by Order of 2 June 2016 appointed the team responsible for drawing up amendments to legal acts concerning advertisement of medicinal products and dietary supplements. ${ }^{23}$ In the report

18 Fry, J. N., Family branding and consumer brand choice, "Journal of Marketing Research" 1986, Vol. 4, No. 3, p. 237, DOI:10.2307/3149455 (accessed 01.02.2020).

19 Blum, J., Trademarks in the pharmaceutical sector: the dynamic between brands, proprietary names and labelling regulations, in: Alemanno A. (ed.). The new intellectual property of health beyond plain packaging, Cheltenham 2016, p. 133.

20 Mruk, H. et al., Marketing strategiczny na rynku farmaceutycznym, Warszawa 2014, p. 78.

21 Act of 16 April 1993 on combating unfair competition, Dz.U. (Journal of Laws) of 1993, No. 47, item 211, as amended, hereinafter also UCA.

22 Act of 23 August 2007 on the prevention of unfair market practices, Dz.U. (Journal of Laws) of 2007, No. 171, item 1206, as amended, hereinafter also PUMPA.

23 Order of the Minister of Health of 2 June 2016 on appointing the Team for regulating the advertising of medicines, dietary supplements and other foodstuff and medicinal products, Dz. Urz. Min. Zdr. (Official Journal of the Minister of Health) of 2016, item 59. 
of the Team for regulating the advertising of medicines, dietary supplements and other foodstuff and medical devices of 1 September 2016 it was proposed that, among others, using umbrella brands in the pharmaceutical market be completely banned. ${ }^{24}$ In compliance with the position presented by the Supreme Pharmaceutical Chamber, Article 53a of the following wording should be added to the PhL: 'The use of umbrella branding with regard to medicinal products, dietary supplements, other foodstuffs and medical devices shall be forbidden'.

\section{Advertising of medicinal products and dietary supplements - selected practical aspects}

While observing advertisements of medicinal products and dietary supplements, a number of irregularities and measures aimed at misleading consumers can be noticed. Dietary supplements are launched, presented and advertised under the name 'a dietary supplement'. If this type of a product is marked with an additional trade name, the phrase 'a dietary supplement' should be placed in the immediate proximity of this name. ${ }^{25}$ While watching commercials of dietary supplements it can be observed that this phrase is often written in very small font, often "blurred", which, in practice makes this information invisible for consumers. ${ }^{26}$ At the same time, paragraph 2 of Article 7 of the Unfair Commercial Practices Directive sets forth that it shall also be regarded as a misleading omission when a trader hides or provides 'the material information in an unclear, unintelligible, ambiguous or untimely manner. ${ }^{27}$

A frequent measure applied in advertising dietary supplements is to use the image of a person from the medical or pharmaceutical circles, as well as reference to the recommendations of persons with such education. It causes the recipients of such advertisements to have a misleading perception of the product, since the

24 The Ministry of Health, Raport Zespolu ds. uregulowania reklamy leków, suplementów diety i innych środków spożywczych oraz wyrobów medycznych, 2016, https://www.gov.pl/web/zdrowie/ (accessed 20.02.2020).

25 Supreme Audit Office, op. cit.

26 Makowska, M. and Jasiński, Ł., A discussion of the unresolved 2016/17 plans for regulating the Polish dietary supplements market, "Health Policy" 2019, Vol. 123, No. 6, p. 557, DOI: 10.1016/j. healthpol.2019.04.001 (accessed 1.02.2020).

27 Directive 2005/29/EC of the European Parliament and of the Council of 11 May 2005 concerning unfair business-to-consumer commercial practices in the internal market and amending Council Directive 84/450/EEC, Directives 97/7/EC, 98/27/EC and 2002/65/EC of the European Parliament and of the Council and Regulation (EC) No 2006/2004 of the European Parliament and of the Council ('Unfair Commercial Practices Directive'), OJ L 149, 11.6.2005, pp. 22-39, p. 27. 
willingness to purchase a given product is mainly based on the authority of persons presented in the advertisement. ${ }^{28}$

The Act on the prevention of unfair market practices provides consumers with protection in the case of entrepreneurs applying unfair practices, that is, entrepreneurs' non-compliance with good practices and significantly distorting or possibly distorting the market behaviour of an average consumer before conclusion of a contract regarding the product, during or after the conclusion thereof. With regard to advertising, unfair market practices include, among others: advertising a product similar to a product of another entrepreneur in a manner purposefully suggesting to the consumer that this product has been manufactured by the same entrepreneur, if it is not compliant with the truth (Article 7 point 13 PUMPA), or stating that the product is able to cure diseases, disorders or malformations, if it is not compliant with the truth (Article 7 point 17 PUMPA).

Moreover, it is inadmissible to use phrases suggesting that the given dietary supplement has features preventing diseases. The Supreme Administrative Court in its judgement of 25 November 2011 deemed such phrases as stating that a given dietary supplement recommended in case of feeling bad while travelling: 'helps in ailments', 'is a solution for motion sickness', 'does not cause side effects. ${ }^{29}$ The message was deemed as one that can imply to a potential consumer that consuming this product helps in ailments and even treats them as in the case of medicinal products. Furthermore, the court stated that the phrase 'does not cause side effects' can be identified by an average consumer without in-depth knowledge in the scope of the pharmaceutical law with the term 'adverse reactions', whereas the latter was used in Article 2 point $3 \mathrm{PhL}$, and is used with regard to medicines.

In compliance with Article 3 par. 2 of the Act on combating unfair competition, misleading markings of goods or services constitutes an act of unfair competition. Moreover, in compliance with Article 10 of this Act, marking goods in a manner that may be misleading for customers with regard to their origin, quantity, quality, ingredients, manner of production, usefulness, possibility to apply, repair, possibility of maintenance or other significant features of goods or services, as well as concealing the risk related to application thereof is forbidden. Article 16 UCA bans illegal and misleading advertisements, which can influence consumers' decisions regarding purchasing goods. The aforementioned regulations can apply in horizontal relation towards entities in mutual competitive relations, since the behaviour of one of them violating the law influences gaining market advantage with regard to

28 Judgement of the Court of Appeal in Warszawa of 16 September 2014, VI ACa 1858/13.

29 Judgement of the Supreme Administrative Court of 25 November 2011, II OSK 1689/10 NSA. 
the competitor not applying such practices. Moreover, in the scope of advertising, an act of unfair competition comprises a message referring to consumers' feelings by causing fear or exploiting the gullibility of children. ${ }^{30}$

The Act on competition and consumer protection ${ }^{31}$ gives the President of the Office of Competition and Consumer Protection the competence to issue decisions regarding practices violating the collective interests of consumers. In compliance with Article 106 of the indicated legal act, the amount of the financial penalty imposed on the entrepreneur cannot be higher than $10 \%$ of the turnover generated in the financial year preceding the year of imposing the penalty, if this entrepreneur even unintentionally violates the collective interests of consumers.

In 2017 the President of the Office of Competition and Consumer Protection identified advertisements of dietary supplements disseminated in the years 2015 and 2016 as a practice violating collective interests of consumers and pursuant to Article 106 par. 1 point 4 of the said Act imposed a financial penalty in the amount of almost PLN 26 million. ${ }^{32}$ The questioned video messages misled consumers with regard to the product's features, usefulness, capacities and expected results of using the product, as well as related benefits of dietary supplements by suggesting that this product has medicinal properties. Furthermore, in the course of the proceedings, upon the commission of the Office of Competition and Consumer Protection, sociological research concerning the impact of the commercials in question on the understanding and perception of advertised dietary supplements by consumers was conducted. The research showed that a large group of consumers believed that the advertised products have medicinal properties.

As a result of the appeal against the decision of the President of the said Office, the District Court in Warszawa in its judgement of 13 January 2020 indicated that the Act on competition and consumer protection provides the President of the Office of Competition and Consumer Protection with the general competence to issue decisions in matters regarding practices violating collective interests of consumers. ${ }^{33}$ In compliance with Article 103 par. 1 point $1 \mathrm{~b}$ FNSA, non-adherence to the requirements in the scope of marking foodstuffs is punishable with a financial penalty in the amount of up to thirty times the average monthly remuneration in

30 Kondrat, M., op. cit., p. 73.

31 Act of 16 February 2007 on competition and consumer protection, Dz.U. (Journal of Laws) of 2007, No. 50, item 331, as amended, Article 24 and Article 106.

32 Decision of the President of the Office of Competition and Consumer Protection of 12 October 2017, no. DOIK 5/2017.

33 Judgement of the Regional Court, the Court of Competition and Consumer Protection of 13 January 2020, XVII AmA 12/18. 
the national economy for the preceding year, imposed by the relevant state voivodeship sanitary inspector in the form of a decision. The Court of Competition and Consumer Protection in its judgement indicated that in compliance with the principle lex specialis derogat legi generali Article 103 par. 1 point 1b FNSA excludes from competences of the President of the Office of Competition and Consumer Protection the possibility to impose financial penalties for practices against collective interests of consumers, the illegality of which consists in infringing the above norm. It should be noticed that financial penalties, which may be imposed pursuant to Article 103 par. 1 point $1 \mathrm{~b}$ FNSA due to misleading advertisements of dietary supplements, are not acute.

\section{Conclusions}

Advertisements for pharmaceutical products and dietary supplements often mislead patients or consumers and expose them to negative health consequences; thus, consumers are not sufficiently covered with relevant legal protection. Due to the specific features differentiating medicines from other products, relevant legal regulations concerning advertisement thereof are necessary. The aim of those provisions should be to minimise the situation of consumption thereof unjustified with medical reasons, since using medicinal products always involves a health risk. Adverse reactions or even detrimental interactions cannot be excluded. Medicinal products and dietary supplements are available in pharmacies and, what is more, dietary supplements are often presented in advertisements similarly to medicinal products. Therefore, there is a close relationship with advertisement of these product categories, however, in the current legal status, this issue is regulated in an extremely different manner. A necessary measure aimed at strengthening the legal protection of patients and consumers undoubtedly involves regulation of the practice of umbrella branding, which is often applied to medicinal products and dietary supplements.

Moreover, control tests conducted among consumers before launching products can be introduced in order to verify consumers' behaviours with regard to products belonging to different categories. Packaging and name should properly differ from existing products so that consumers can easily differentiate the new product with changed ingredients. Conducting diagnostic tests in order to verify whether a given product can be safely differentiated within a given product category and whether using the product is safe. Such measures will help disclose and possibly prevent certain problems related to the usefulness of a given new product. At the same time, it should be noted that sometimes the penalties for misleading advertising are not high enough. 


\section{References}

Blum, J., Trademarks in the pharmaceutical sector: the dynamic between brands, proprietary names and labelling regulations, in: Alemanno A. (ed.). The new intellectual property of health beyond plain packaging, Cheltenham 2016.

Fry, J.N., Family branding and consumer brand choice, "Journal of Marketing Research" 1986, Vol. 4, No. 3, DOI:10.2307/3149455.

Ignatowicz, Z., Reklama produktów leczniczych, in: Olszewski, W.L. (ed.) Prawo farmaceutyczne. Komentarz, Warszawa 2016.

Kondrat, M. et al., Prawo suplementów diety, Warszawa 2012,

Ministry of Health, Polityka Lekowa Państwa 2018-2022, 2018, https:/www.gov.pl/web/ zdrowie.

Makowska, M. and Jasiński, Ł., A discussion of the unresolved 2016/17 plans for regulating the Polish dietary supplements market, "Health Policy" 2019, Vol. 123, No. 6, DOI: 10.1016/j.healthpol.2019.04.001.

Mokrysz-Olszyńska, A., Reklama suplementów diety jako wyzwanie dla ustawodawcy i regulatora, "Roczniki Administracji i Prawa" 2016, Vol. 16(2).

Mruk, H. et al., Marketing strategiczny na rynku farmaceutycznym, Warszawa 2014.

Pierewoj, J., Suplement diety a bezpieczeństwo konsumentów - wybrane aspekty prawa polskiego oraz prawa Unii Europejskiej, in: Porzeżyński, M. and Borcuch, A. (eds.), Bezpieczeństwo $w$ erze społeczeństwa informacyjnego. Wyzwania $w$ sferach kultury, marketingu i gospodarki, Kielce 2019.

Roszak, M., Granice stosowania praktyki umbrella brandingu (znaków parasolowych) na rynku farmaceutycznym, in: Kępiński, M. (ed.), Rynek farmaceutyczny, a prawo własności intelektualnej, Warszawa 2013.

Supreme Audit Office, Dopuszczenie do obrotu suplementów diety, 2017, https://www. nik.gov.pl/.

Szczęsny, R., Reklama farmaceutyczna i pokrewna, Warszawa 2010.

Ministry of Health, Raport Zespołu ds. uregulowania reklamy leków, suplementów diety $i$ innych środków spożywczych oraz wyrobów medycznych, 2016, https://www.gov.pl/ web/zdrowie/.

\section{CITATION}

Pierewoj, J., Misleading advertising practices for medicinal products and dietary supplements selected legal and practical aspects, "Acta Iuris Stetinensis" 2020, No. 4 (Vol. 32), 65-75, DOI: 10.18276/ais.2020.32-05. 